\title{
The protective role of vitamin $C$ against chlorine-induced lung injury in adult albino rats : Histological and immunohistochemical study
}

\author{
Original \\ Amgad Gaber Elsaid, Rehab T. Khattab \\ Article \\ Anatomy and Embryology Department, Faculty of Medicine, Ain-Shams University, Cairo, \\ Egypt
}

\begin{abstract}
Introduction: The lung is the primary organ for inhaled irritants. Chlorine $(\mathrm{Cl} 2)$ has high solubility in water. It can dissolve into epithelial lining fluid when contacting mucosal surfaces. Vitamin C provided an important antioxidant defense against hypochlorous acid-mediated injury in atherosclerosis. Vitamin $\mathrm{C}$ supplementation decreased lipid and protein oxidation in vivo.

Aim: To study the possible protective role of Vitamin $\mathrm{C}$ against the toxic effects of $\mathrm{Cl} 2$ on the lung of adult albino rats with special emphasis on the vascular endothelial growth factor (VEGF).

Materials and Methods: Forty male rats were divided into four equal groups. Group (A) control rats, group (B) rats received Vitamin C (500 mg/kg) orally once per day for 8 weeks, group (C) rats were exposed to $\mathrm{Cl} 2$ for $4 \mathrm{~h}$ daily for of 8 weeks and group (D) Cl2-Vitamin C group received Vitamin C and exposed to $\mathrm{Cl} 2$ as in group B and C. At the end of the experiment lungs were prepared and stained with H\&E, Masson's trichrome and immunohistological stain for VEGF. Results: Examination of specimens of group $\mathrm{C}$ showed marked loss of normal architecture. The lung showed widen alveoli containing vacuolated acidophilic exudate entangled with polymorph nuclear leucocytes. The wall of the bronchioles showed vacuolated acidophilic exudate. Lung specimens stained by Masson's trichrome stain showed increased collagen deposition around the bronchioles and the blood vessels. Also this group showed strong positive reaction to vascular endothelial growth factor (VEGF). Group D showed improved lung architecture and VEGF moderate reaction.

Conclusion: $\mathrm{C} 22$ has destructive changes in the architecture of the lung. In addition, it creates a case similar to hypoxia indicated by strong reaction to VEGF that has been ameliorated by vitamin C.
\end{abstract}

Revised: 14 March 2016, Accepted: 29 September 2017

Key Words: Chlorine, vitamin C, lung, rat.

Corresponding Author: Amgad Gaber Elsaid, Faculty of Medicine, Ain-Shams University, Cairo, Egypt, Tel.: 01006042491, E-mail: amgadana@yahoo.com.

ISSN: 1110-0559, Vol. 40, No.4

\section{INTRODUCTION}

Chlorine $(\mathrm{Cl} 2)$ is a highly reactive oxidant gas widely used in many industries. $\mathrm{Cl} 2$ is used in the manufacture of paper, plastics, solvents, cleaning agents, pharmaceuticals and textiles. $\mathrm{Cl} 2$ is one of the most commonly used disinfectants for the drinking water and for the swimming $\operatorname{pools}^{[1]}$.

Accidental exposure to $\mathrm{Cl} 2$ is relatively common in the industrial release, transportation mishaps, swimmingpools' preparations and even in household release through inappropriate mixing of domestic cleaning agents, such as hypochlorite (bleach) and acids (cleaners) ${ }^{[2]}$.

$\mathrm{Cl} 2$ exposure can result in injury to the eyes, skin, and airways. The airway is especially affected from the nose to the level of the bronchi. Few years ago, it has been suggested that there is a strong correlation between chronic lung exposure to $\mathrm{Cl} 2$ and the rising numbers of patients with asthma ${ }^{[3]}$. Moreover, high dose exposures may lead to acute lung injury and death ${ }^{4]}$.

The respiratory tract is the primary organ for inhaled irritants. $\mathrm{Cl} 2$ has higher solubility in water than other strong irritants such as ozone. It can form hypochlorous acid and hydrochloric acid (HCL) as it dissolves readily into epithelial lining fluid when contacting mucosal surfaces and airways ${ }^{[5]}$.

$\mathrm{Cl} 2$ also causes direct oxidative injury to the epithelium with subsequent migration and activation of inflammatory cells within the airway epithelium, together with release of oxidants $^{[2]}$.

Following Cl2-induced injury, lung management doesn't regain its normal function and structure. Subepithelial fibrosis, mucous hyperplasia, and nonspecific airway hyper-responsiveness have been commonly reported after recovery from $\mathrm{Cl} 2$ injury ${ }^{[6]}$. 
Vitamin C (ascorbate) is an aqueous phase antioxidant in biological fluids. It presents in relatively high concentrations in the epithelial lining fluid and lung tissues. Vitamin C levels in alveolar macrophages are 30 times higher than that in plasma $^{[7]}$.

Deficiency of vitamin $\mathrm{C}$ causes oxidative stress and tissue injury. Also, its supplementation protects against the effect of ozone on the pulmonary function of asthmatic children $^{[8]}$. It also provides an important antioxidant defense against hypochlorous acid-mediated injury in atherosclerosis ${ }^{[9]}$. Moreover, it can decrease lipid and protein oxidation in vivo ${ }^{[10]}$.

\section{AIM OF THE WORK}

This research aimed to study the possible protective role of Vitamin $\mathrm{C}$ against the toxic effects of $\mathrm{Cl} 2$ on the histology of the lung of adult albino rats with special emphasis on the vascular endothelial growth factor (VEGF).

\section{MATERIALS AND METHODS}

\section{Experimental animals}

Forty healthy adult male albino rats aged six month, locally bred at the animal house of Bilharzial Research Unit, Faculty of Medicine, Ain Shams University. Rats were treated in accordance with guidelines approved by the animal Committee of Ain Shams University. The rats were housed in stainless steel cages. The rats were exposed to dark/light cycle and allowed daily diet and free water access with suitable environmental conditions and good ventilation.

The rats were divided into four groups; 10 rats, each.

Group A "The control group" exposed to a nebulized distilled water

Group B "Vitamin C-exposed group" rats received Vitamin C at a dose of $500 \mathrm{mg} / \mathrm{kg}$, via gastric tube once per day for eight weeks.

Group C "Cl2-exposed group" rats were exposed to Chlorine four hours daily for a period of eight weeks.

Group D "Cl2/Vitamin C group" rats were exposed to Chlorine the same as in group $\mathrm{C}$, together with oral administration of Vitamin $\mathrm{C}$ at the same dose as in group B.

\section{Exposure to Cl2:}

Rats were exposed for 20 minutes to a nebulized $4 \%$ sodium hypochlorite or its vehicle (distilled water in control group) using a nebulizer (Norditalia Elettromedicali S.R.L-25010 S. Martino della Battaglia - Italy) to deliver the aerosol at a rate of $0.25 \mathrm{ml} / \mathrm{min}^{[11]}$.

\section{Administration of Vitamin C}

Vitamin C was administered orally at a dose of $500 \mathrm{mg} /$ $\mathrm{kg}$ body wt, via gastric tube ${ }^{[12]}$.
At the end of the experiment, the animals were sacrificed by high dose of ether anesthesia. The thoracic wall was opened and lungs were dissected. The specimens were fixed in $10 \%$ formalin, sliced and processed for paraffin embedding. Sections of $5 \mu \mathrm{m}$ were cut and stained with Haematoxylin and Eosin (H\&E) and Masson's trichrome stain $^{[13]}$ for their histopathological examination.

\section{Immunohistochemical study}

Lung sections were prepared and heated in an oven for 25 minutes at $60^{\circ} \mathrm{C}$. After heating, lung sections were deparaffinized in xylene and rehydrated in graded alcohol. Succinctly, $0.03 \%$ hydrogen peroxide sodium azide was used to block the endogenous peroxidase for $5 \mathrm{~min}$ followed by washing the tissue sections carefully using wash buffer and then incubated with the VEGF antibody. Diaminobenzidine substrate chromagen was applied to the sections and reincubated for over $8 \mathrm{~min}$ followed by careful washes. The sections were finally counterstained with hematoxylin ${ }^{[14]}$.

\section{RESULTS}

\section{Group A "Control group"}

Lung sections of the group (A) revealed that, the lung composed of several variable sized alveoli with clear patent bronchiolar passages and alveolar cavities (Fig. 1). The alveolar wall was thin and lined by two types of epithelial cells (pneumocytes); squamous epithelial cells (pneumocyte Type I) and large cuboidal secretory cells (pneumocyte Type II) that present at the angular junctions of the alveolar walls. Blood vessels were distributed within the pulmonary parenchyma. The alveolar septa had normal thickness with no abnormality in alveolar septal blood capillaries (Fig. 2). Bronchiolar epithelium and para-bronchiolar lymphoid aggregation was also observed (Fig. 3). Masson's trichrome stained sections showed distribution of collagen fibers around the bronchiolar wall and blood vessels (Fig. 4).

Lung sections of this group showed negative staining for VEGF in distal airway epithelial cells, pneumocytes, and endothelial cells (Fig. 5).

Sections of vitamin C exposed group (Group B) showed similar appearance as that of the control group.

\section{Group C "Cl2-exposed group"}

Examination of H\&E-stained sections of this group showed increased cellularity of alveolar wall and thickened alveolar septa, emphysema evident from bulla formation of air spaces and dilated inter-alveolar septal capillaries. However, some alveoli showed rupture of the alveolar septa and interstitial hemorrhage (Fig. 6). The lung showed dilatation of the blood vessels accompanied by infiltration of the alveoli with inflammatory cell specially macrophages which led to increased thickness of the interalveolar septum. Also, some cells expressed shrunken dark pyknotic nuclei (Fig. 7). The lung showed widened alveoli 
containing vacuolated acidophilic exudate entangled with polymorph nuclear leucocytes. The lung parenchyma showed infiltration and aggregation of lymphocytes (Fig. 8). The epithelium of the bronchioles showed necrosis and desquamation. Moreover, the terminal bronchioles containing vacuolated acidophilic exudate entangled with polymorph nuclear leucocytes. Also, there was aggregation of lymphocytes around the terminal bronchiole (Fig. 9).

Masson's trichrome stained sections showed interstitial fibrosis. There was also dilation and thickening of vascular wall, increased smooth muscle thickness around bronchiolar passages (Fig. 10).

VEGF stained section showed strong positive reaction in distal airway epithelial cells, pneumocytes, and endothelial cells (Figs.11 and 12).

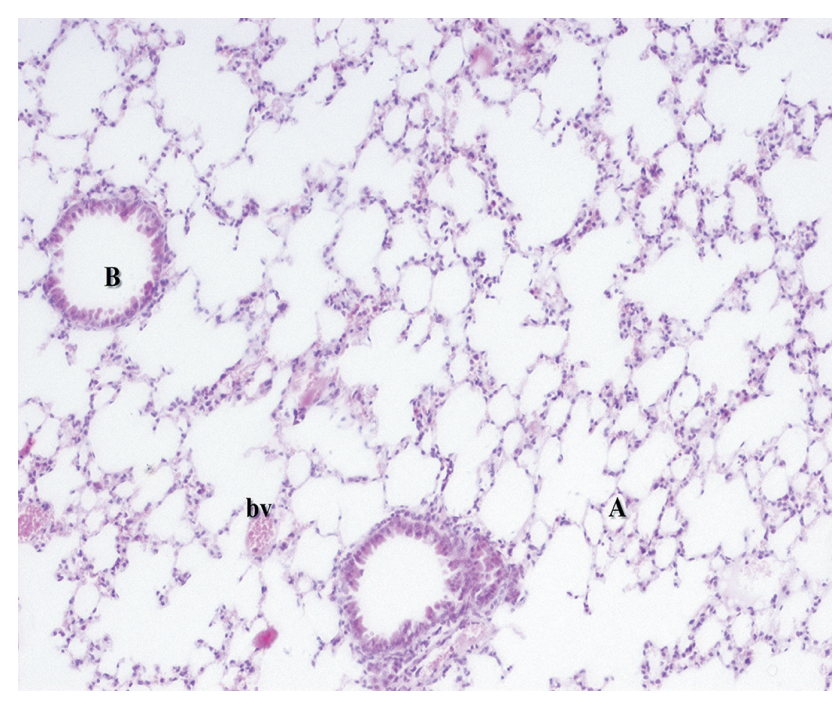

Fig. 1: A photomicrograph of control albino rat lung showing alveoli (A), bronchiole (B) and pulmonary blood vessels (bv).

$\mathrm{H} \& \mathrm{E} ; \times 100$

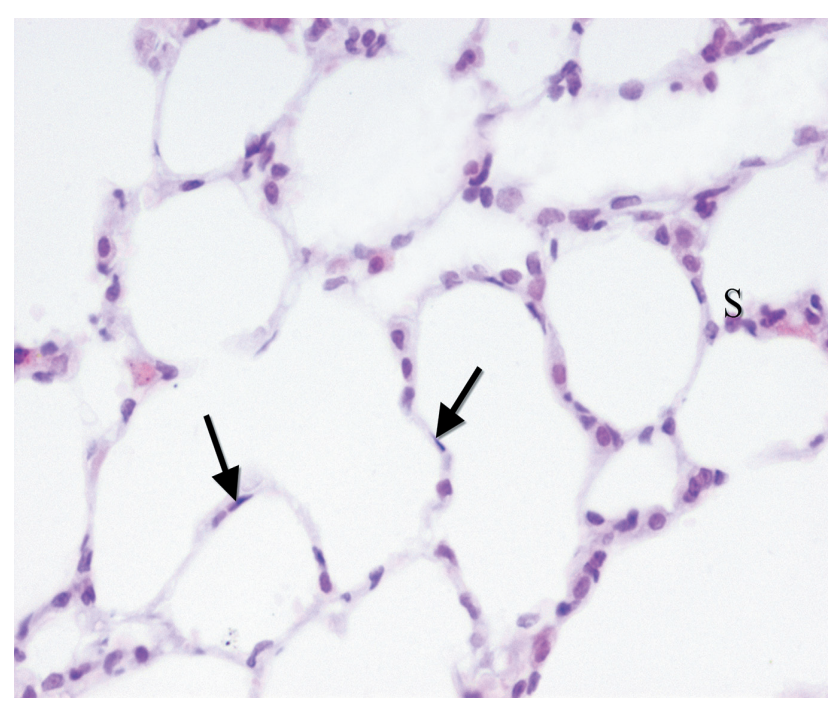

Fig. 2: A photomicrograph of control albino rat lung showing normal lining of the alveoli; pneumocyte Type I $(\uparrow)$ and pneumocyte Type II (S).

$\mathrm{H} \& \mathrm{E} ; \times 400$

\section{Group D" Cl2 and Vitamin-C-exposed"}

Microscopic examination of sections from this group showed that vitamin $\mathrm{C}$ caused improvement in lung parenchyma that showed nearly normal alveoli lined by pneumocytes. The bronchioles were seen intermixed with the alveoli. The intervening stroma was studded with few lymphocytes (Fig. 13). The intervening blood vessels were mildly congested, and the inter-alveolar septa were less thickened (Figs. 14). The bronchioles were lined by simple columnar ciliated epithelium (Figs. 15). Masson's trichrome stained sections showed less collagen fibers around the vessels and the bronchioles (Fig. 16).

VEGF stained sections of this group showed moderate positive reaction (Fig. 17).

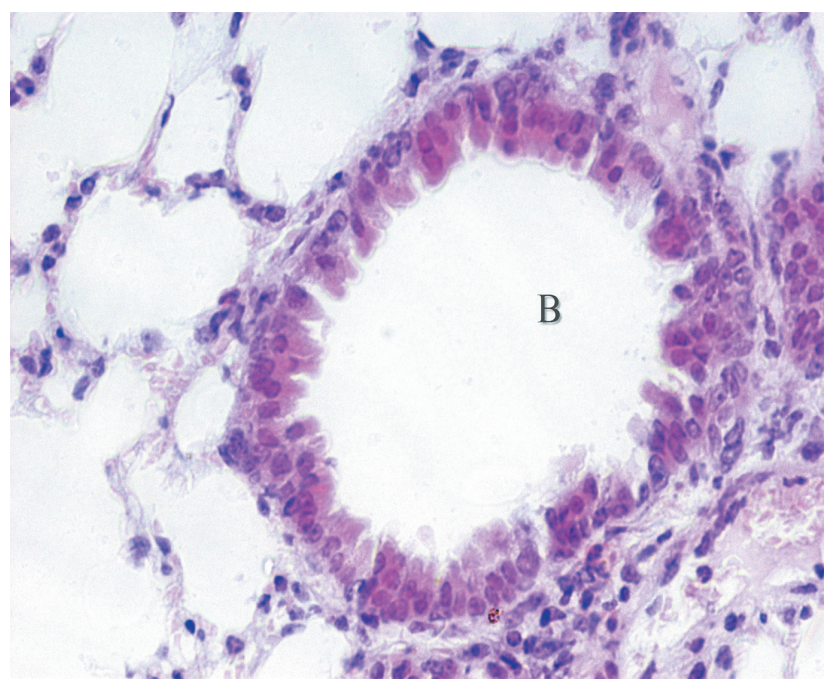

Fig. 3: A photomicrograph of control albino rat lung showing normal bronchiolar epithelium (B).

$\mathrm{H} \& \mathrm{E} ; \times 400$

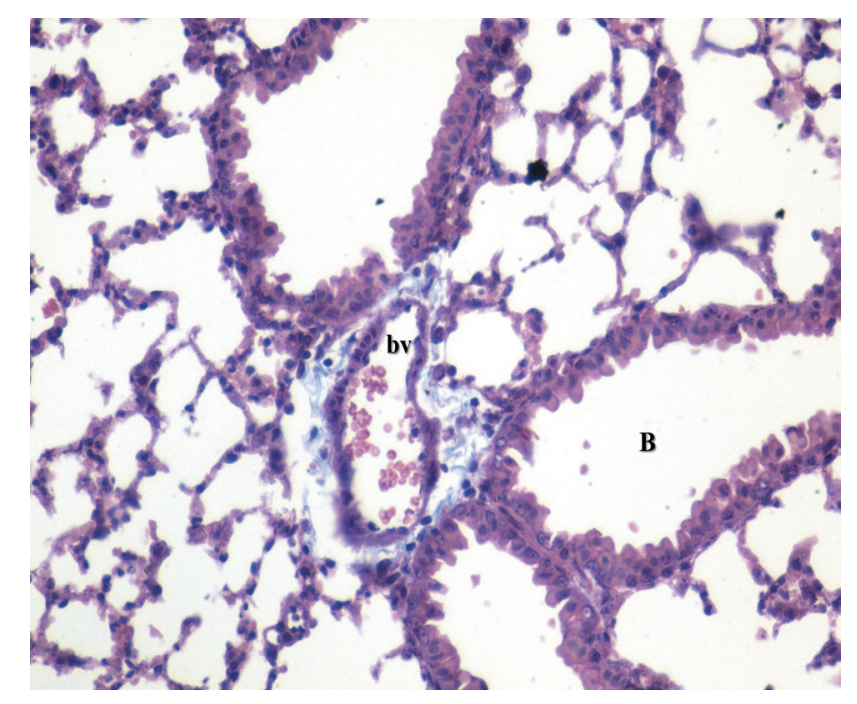

Fig. 4: A photomicrograph of control albino rat lung showing normal collagen distribution around the pulmonary vasculature (bv) and the bronchiole (B).

Masson's trichrome; $\times 400$ 


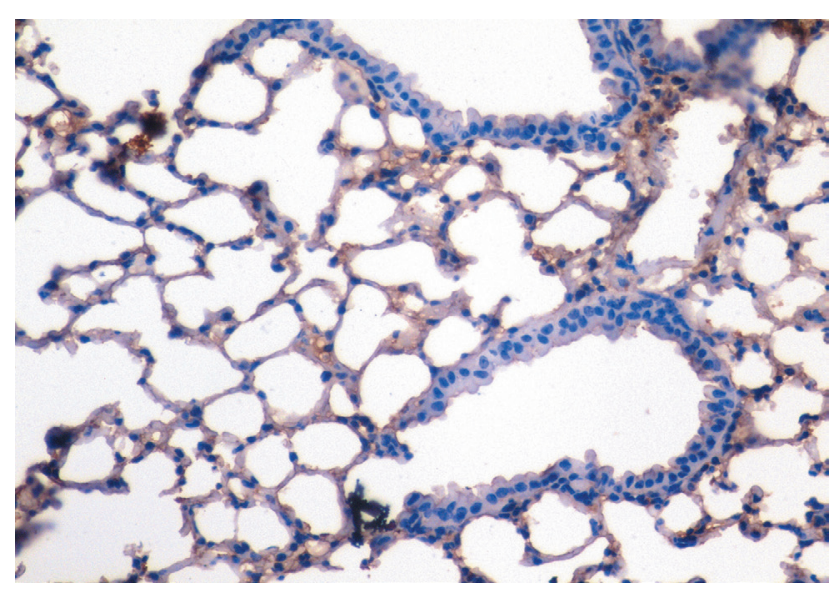

Fig. 5: A photomicrograph of control albino rat lung showing negative staining for VEGF in distal airway epithelial cells, pneumocytes and endothelial cells.

VEGF; $\times 400$

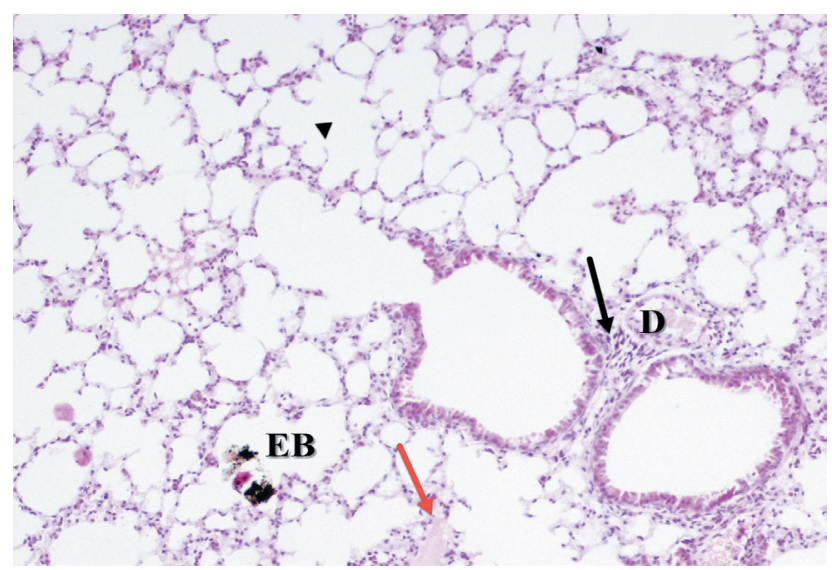

Fig. 6: A photomicrograph of $\mathrm{Cl} 2$ exposed albino rat lung showing emphysematous bullae (EB) dilated capillaries (D), rupture of the alveolar septa $(\boldsymbol{\Delta})$ and interstitial hemorrhage (red arrow). Notice Local infiltration of lung parenchyma by lymphocytes (black arrow).

$\mathrm{H} \& \mathrm{E} ; \times 100$

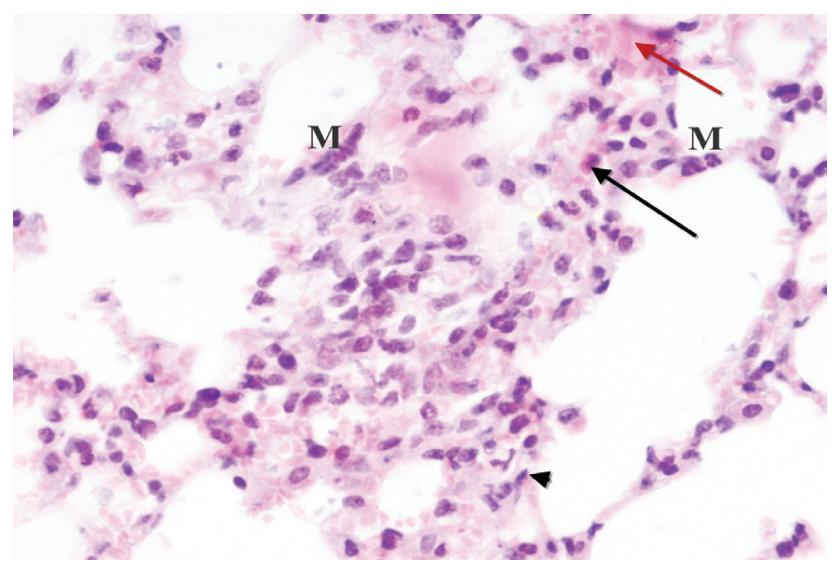

Fig. 7: A photomicrograph of $\mathrm{Cl} 2$ exposed albino rat lung showing thickened alveolar septa $(\boldsymbol{\Lambda})$, increase of macrophages (M), pyknotic nuclei (arrow) and interstitial hemorrhage (red arrow).

$\mathrm{H} \& \mathrm{E} ; \times 400$

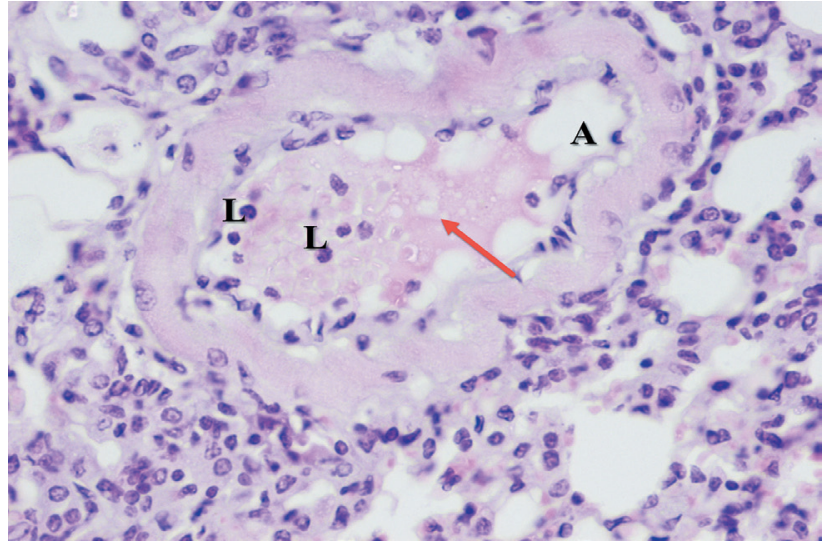

Fig. 8: Photomicrographs of $\mathrm{Cl} 2$ exposed albino rat lung showing widened alveolus (A) containing vacuolated acidophilic exudate (red arrow) entangled with polymorph nuclear leucocytes (L).

$\mathrm{H} \& \mathrm{E} ; \times 400$

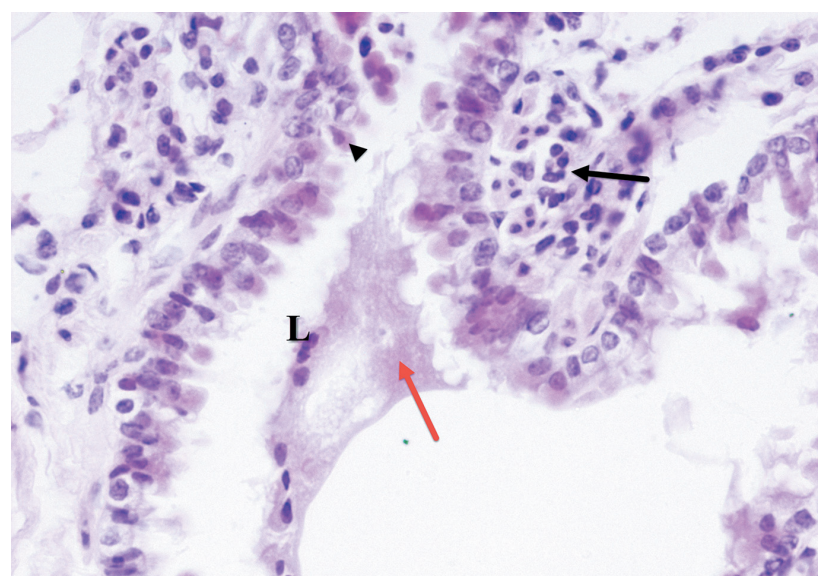

Fig. 9: A photomicrograph of $\mathrm{Cl} 2$ exposed albino rat lung showing alteration of bronchial epithelium resulting in necrosis and desquamation $(\boldsymbol{\Delta})$, the terminal bronchiole containing vacuolated acidophilic exudate (red arrow) entangled with polymorph nuclear leucocytes (L). Notice aggregation of lymphocytes around the terminal bronchiole $(\uparrow)$.

$\mathrm{H} \& \mathrm{E} ; \times 400$

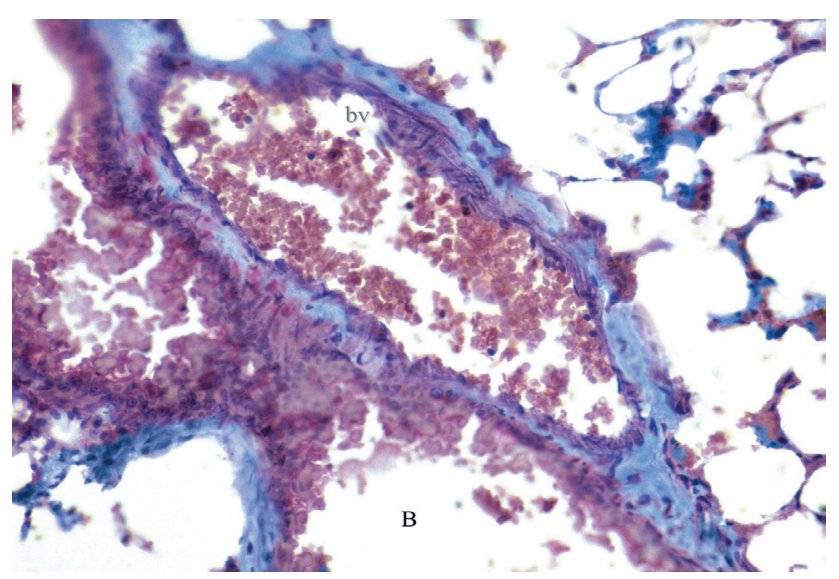

Fig. 10: A photomicrograph of $\mathrm{Cl} 2$ exposed albino rat lung showing dilated thickened blood vessels (bv) and increased smooth muscle thickness around bronchiolar passages (B). Notice the Interstitial fibrosis.

Masson's trichrome; $\times 400$ 


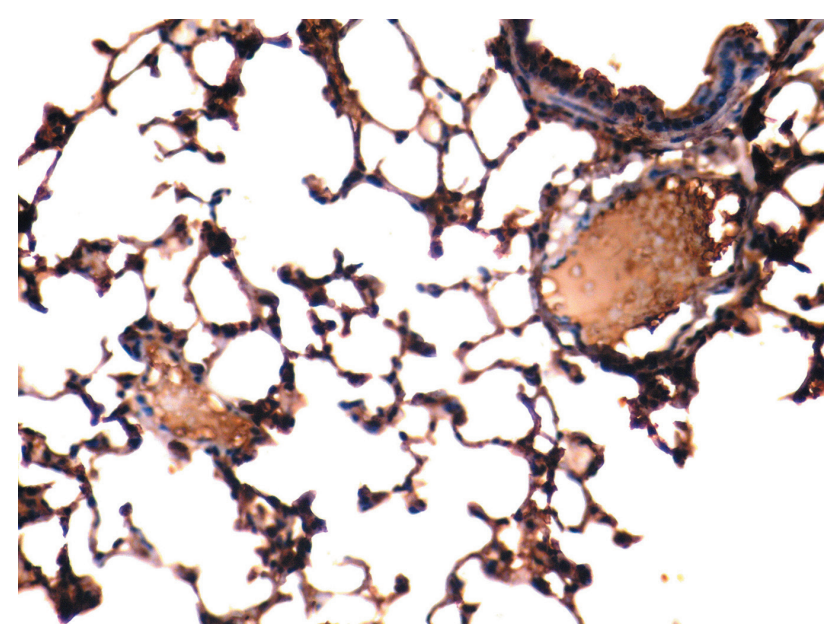

Fig. 11: A photomicrograph of $\mathrm{Cl} 2$ exposed albino rat lung showing strong positive immunoreactivity for VEGF in distal airway epithelial cells and pneumocytes.

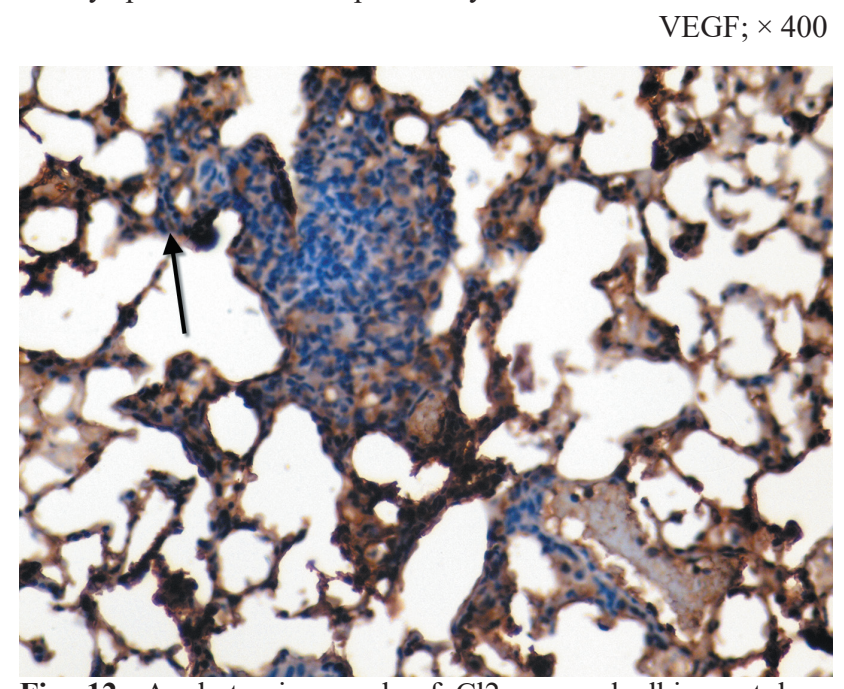

Fig. 12: A photomicrograph of $\mathrm{Cl} 2$ exposed albino rat lung showing strong positive staining for VEGF in bronchiolar epithelial cells and endothelial cells $(\uparrow)$.

VEGF; $\times 400$

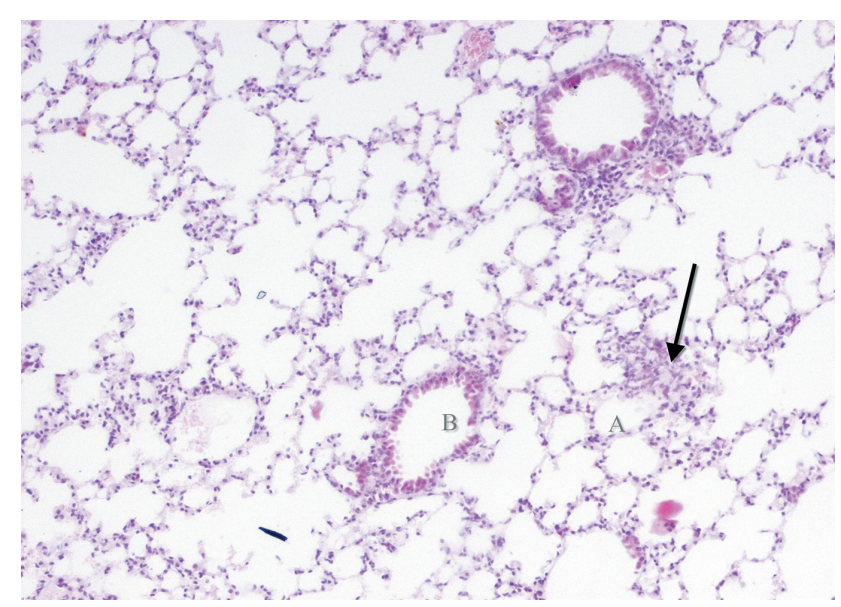

Fig. 13: A photomicrograph $\mathrm{Cl} 2$ and Vitamin $\mathrm{C}$ exposed albino rat lung showing several variably sized alveoli (A). The bronchioles (B) were seen intermixed with the alveoli. The intervening stroma was studded with few lymphocytes $(\uparrow)$.

$\mathrm{H} \& \mathrm{E} ; \times 100$

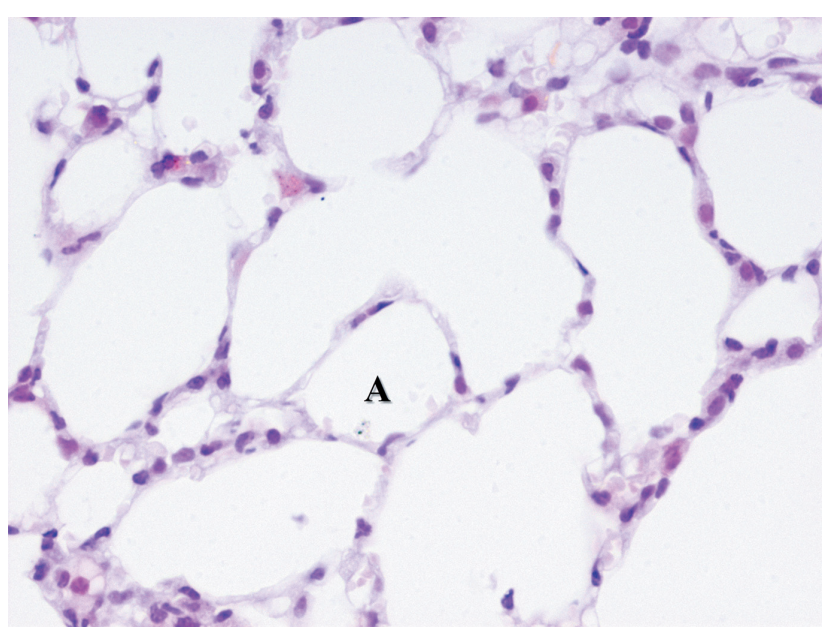

Fig. 14: A photomicrograph of $\mathrm{Cl} 2$ and Vitamin $\mathrm{C}$ exposed albino rat lung showing several variably sized alveoli (A) lined by pneumocytes.

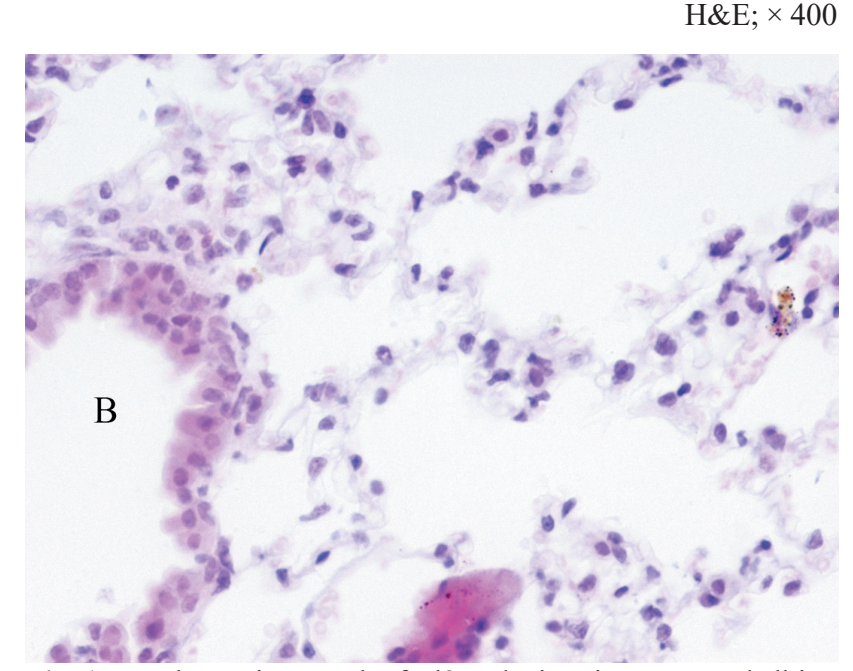

Fig. 15: A photomicrograph of $\mathrm{Cl} 2$ and Vitamin $\mathrm{C}$ exposed albino rat lung showing the bronchi (B) were lined by simple columnar ciliated epithelium.

$\mathrm{H} \& \mathrm{E} ; \times 400$

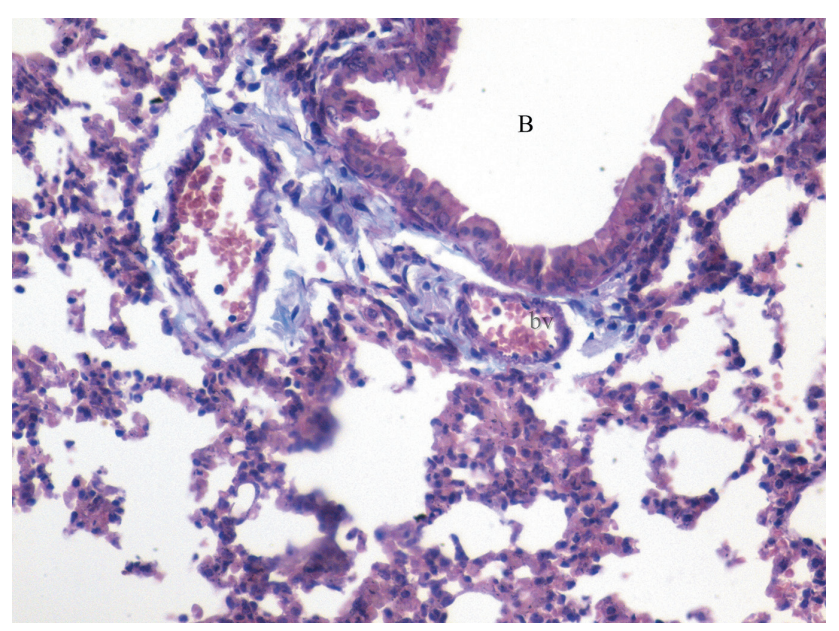

Fig. 16: A photomicrograph of $\mathrm{Cl} 2$ and Vitamin $\mathrm{C}$ exposed albino rat lung showing collagen fibers deposition around the blood vessels (bv) and terminal bronchioles (B).

Masson's trichrome; $\times 400$ 


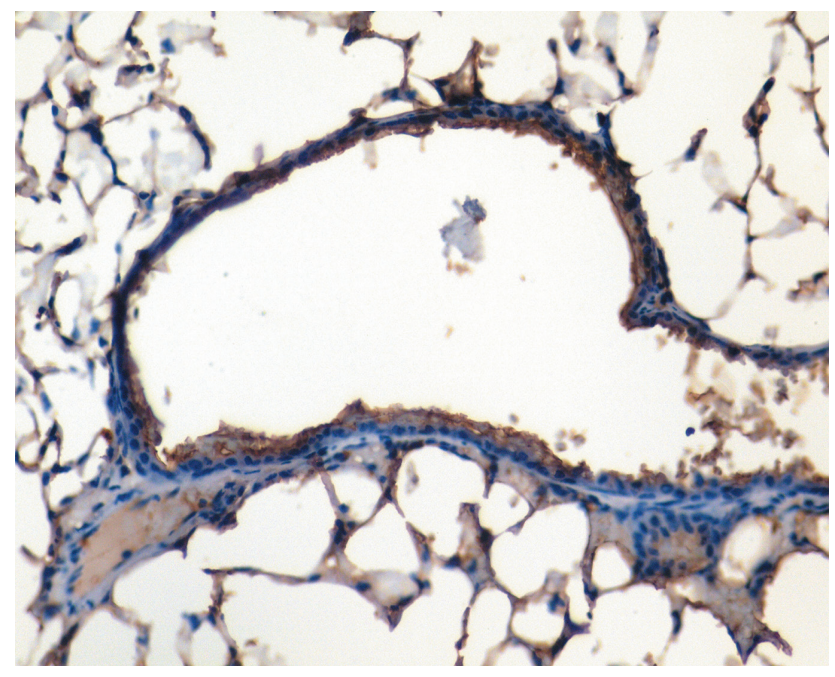

Fig. 17: A photomicrograph of $\mathrm{Cl} 2$ and Vitamin $\mathrm{C}$ exposed albino rat lung showing weak positive staining for VEGF in the pneumocytes.

VEGF $; \times 400$

\section{DISCUSSION}

CL2 is a commonly used chemical in industry and society. Exposures to toxic levels of $\mathrm{Cl} 2$ are generally accidental. The use of bleach combined with HCL in developing or developed societies causes a variety of abnormalities ranging from mild airways dysfunction to acute lung injury with fatality ${ }^{[15]}$

$\mathrm{Cl} 2$ exposure causes irritant effects when it comes in contact with mucosal membranes within the respiratory tract. It is able to react with water on the moist surface of the respiratory airways following the inhalation. This reaction causes marked lower and upper respiratory tracts injury ${ }^{[16]}$.

The formation of hydrochloric and hypochlorous acids could cause acid injury. However, the toxicity of chlorine is attributed to other mechanisms. Hypochlorous acid may interact with hydrogen peroxide to form the hydroxyl radical. The production of these free radicals explains the presence of the inflammatory cells within alveolar walls $^{[2]}$.

The histopathological examination of the lungs in Group C revealed sloughing of bronchiolar epithelial and replacement of the cuboidal epithelium with flat cells. Similar findings were observed by Yildirim et al. ${ }^{[17]}$.

The toxic mechanism of action of $\mathrm{Cl} 2$ on the living cells is believed to be due to production of reactive hypochlorite ions, hypochloric acid and the free chloride ion which interact as a powerful oxidizing agent with the sulfhydryl groups and sulfur bonds of the cellular proteins ${ }^{[2]}$.

The current study showed rupture of the alveolar septa and alveolar damage. Emphysematous alterations and interstitial fibrosis was reported in some of the rats at the end of 45 days exposure to $\mathrm{Cl} 2^{[18]}$.

In addition, Masson's trichrome stained sections revealed increased lung collagen deposition in $\mathrm{Cl} 2$ inhaled rats. That was previously explained on the basis of alterations in both the synthetic and degradative pathways of collagen homeostasis ${ }^{[19]}$.

The alveolar epithelial loss, caused by apoptosis, is a common finding in pulmonary fibrosis ${ }^{[20]}$.

The present work showed congestion, interstitial and alveolar edema in the lung tissue of rats exposed to CL2. Also, Menaouar et al. ${ }^{[21]}$ reported an increase in microvascular permeability that leads to alveolar flooding within minutes of exposure of the isolated lung to $\mathrm{Cl} 2$.

Significant amounts of hypochlorous acid are generated during $\mathrm{Cl} 2$ inhalation. The main targets of hypochlorous acid are free functional groups of proteins and amino acids, predominantly sulfhydryl groups, free amine groups of plasma amino acids yielding chlorinated amines thus damaging a number of key proteins, altering their functions and increasing permeability to plasma proteins ${ }^{[22]}$.

Injury to either apical or basolateral pathways may lead to impairment of fluid reabsorption, which in turn may result in pulmonary edema, hypoxemia and eventually death from respiratory failure ${ }^{[23]}$.

The airway epithelium is the first target of inhaled $\mathrm{Cl} 2$ gas. It immediately causes direct oxidative injury to the epithelium, but further damage to the epithelium may occur with infiltration of inflammatory cells, such as neutrophils, into the airway epithelium with subsequent release of inflammatory cytokines and proteolytic enzymes that finally lead to airway hyper-responsiveness ${ }^{[24]}$.

In this study, the $\mathrm{Cl} 2$ exposed group showed strong positive staining for VEGF. Rats exposed to $\mathrm{Cl} 2$ gas developed moderate hypoxemia and hypercapnia ${ }^{[5]}$. It is assumed that exposure to $\mathrm{Cl} 2$ developed acute lung injury and needed mechanical ventilation and oxygen supplementation to overcome arterial hypoxemia ${ }^{[25]}$. Levels of VEGF in bronchoalveolar fluid from Cl2-exposed mice showed increasing levels ${ }^{[26]}$. Noteworthy, no significant changes detected in VEGF after Short-term swimming in a chlorinated pool.

Exposure to $\mathrm{Cl} 2$ led to epithelial cell death, failure of re-epithelialization, inflammatory cell and fibroblast infiltration, collagen deposition, and angiogenesis, ultimately leading to lethal airway obstruction ${ }^{[28]}$.

In this study, $\mathrm{H} \& \mathrm{E}$ stained sections of $\mathrm{Cl} 2$ exposed rats showed thickening of bronchiolar muscular wall that had been previously explained as a sign of increased airway resistance (asthma) which is a well-known consequence of exposure to air pollutants.

The present work showed thickening of vascular wall in $\mathrm{Cl} 2$ exposed group which is considered as 
sign of pulmonary hypertension that could result in cor-pulmonale ${ }^{[30]}$.

The airway smooth muscle hyperplasia was possibly among the sequences of airway remodeling after an acute CL2 exposure in mice ${ }^{[31]}$.

Pretreatment of cells with vitamin C protected against $\mathrm{HOCl}$-induced rapid protein and DNA damage, loss of intracellular GSH and ATP, and highlighting the cytoprotective actions of intracellular vitamin $\mathrm{C}$ against vascular smooth muscle cell damage ${ }^{[9]}$.

Vitamin C (ascorbate) acts as a potent water-soluble antioxidant in biological fluids trapping radicals and protecting biological macromolecules such as DNA, lipids, and proteins. Vitamin $\mathrm{C}$ readily scavenges reactive oxygen species, hydroxyl and hypochlorous acid. It is known to be an important source of electrons and can donate electrons to oxidants or radicals ${ }^{[5]}$.

Vitamin C administration almost completely protects lungs of guinea pigs from protein damage and apoptosis caused by cigarette smoking for 21 days $^{[32]}$. Also, AL Saggaf et al. ${ }^{[33]}$ noted that vitamin $\mathrm{C}$ administration during exposure to gasoline showed less pathological changes in the lung and trachea. Sourour et al. ${ }^{[29]}$ concluded that co-administration of vitamin $\mathrm{C}$ during benzene inhalation in rats reduced the structural changes of trachea and lung and ameliorated the toxic effects of benzene on the lung, attributed to the antioxidant, antiapoptotic and antifibrotic effects of vitamin C.

Masson's trichome stained sections of $\mathrm{Cl} 2$ and vitamin $\mathrm{C}$ treated group showed moderate collagen deposition in the lung interstitium, which is in agreement with Hemmati et al. ${ }^{[34]}$ whereas vitamin $\mathrm{C}$ administration reduced collagen content of lung tissue exposed to hexavalent chromium.

\section{CONCLUSION}

$\mathrm{Cl} 2$ has destructive structural changes in the architecture of the lung, however, vitamin $\mathrm{C}$ possess the protective ability to ameliorate these effects.

We, therefore, recommend to supply persons in risk of long period of exposure to the chlorine with regular doses of vitamin $\mathrm{C}$.

\section{CONFLICT OF INTEREST}

There are no conflicts of interest.

\section{REFERENCES}

1. Evans, R.B. (2005). Chlorine: state of the art. Lung; 183: 151-167.
Winder, C. (2001). The toxicology of chlorine. Envi ronmental Research; 85(2):105-114.

2. Puissant B, Barreau C, Bourin P, Clavel C, Corre J, Bousquet C, Taureau C, Cousin B, Abbal M, Laharrague P, Penicaud L, Casteilla L, Blancher A. Immunomodulatory effect of human adipose tissue-derived adult stem cells: comparison with bone marrow mesenchymal stem cells. $\mathrm{Br} \mathrm{J}$ Haematol 2005; 129: 118-129.

3. Beretta, S., Vivaldo, T., Morelli, M., Carlucci, P. and Zuccotti, G.V. (2011). Swimming pool induced asthma. Journal of Investigational Allergology and Clinical Immunology; 21(3):240-241.

4. Van, S.D., Wenck, M.A., Belflower, A., Drociuk, D., Ferdinands, J., Holguin, F., Svendsen, E., Bretous, L., Jankelevich, S., Gibson, J.J., Garbe, P. and Moolenaar, R.L. (2009). Acute health effects after exposure to chlorine gas released after a train derailment. Am. J. Emerg. Med.; 27:1.

5. Leustik, M., Doran, S., Bracher, A., Williams, S., Squadrito, G.L., Schoeb, T.R., Postlethwait, E. and Matalon, S. (2008). Mitigation of chlorineinduced lung injury by low-molecular-weight antioxidants. Am J Physiol Lung Cell Mol. Physiol.; 295(5): L733-L743.

6. White, C.W. and Martin, J.G. (2010). Chlorine Gas Inhalation Human Clinical Evidence of Toxicity and Experience in Animal Models. Proc. Am. Thorac. Soc.; 7: 257-263.

7. Hemila, HH. (2014). The effect of vitamin C on bronchoconstriction and respiratory symptoms caused by exercise: a review and statistical analysis. Allergy Asthma Clin Immunol.; 10 (1):58.

8. Moreno-Macías, H., Dockery, D.W., Schwartz, J., Gold, D.R., Laird, N.M., Sienra-Monge, J.J., Del Río-Navarro, B.E., Ramírez-Aguilar, M., BarrazaVillarreal, A., Li, H., London, S.J. and Romieu, I. (2013). Ozone exposure, vitamin C intake, and genetic susceptibility of asthmatic children in Mexico City: a cohort study. Respir. Res.; 14:14.

9. Jenner, A.M., Ruiz, J.E., Dunster, C., Halliwell, B., Mann, G.E. and Siow, R.C. (2002). Vitamin C Protects Against Hypochlorous Acid-Induced Glutathione Depletion and DNA Base and Protein Damage in Human Vascular Smooth Muscle Cells. Arteriosclerosis, Thrombosis, and Vascular Biology; 22: 574-580.

10. Yadav, A.K., Bracher, A., Doran, S.F., Leustik, M., 
Squadrito, G.L., Postlethwait, E.M. and Matalon, S. (2010). Mechanisms and Modification of Chlorineinduced Lung Injury in Animals. Proceedings of the American Thoracic Society. 2010; 7(4):278-283.

11. Aboul-Fotouh, S. and Farouk, G.M. (2011). Mitigation of Delayed Sodium HypochloriteInduced Lung Injury by Phosphodiesterase Enzyme Inhibitors (PDEIs), Pentoxifylline and Theophylline, in Guinea Pigs. Egyptian Journal of Basic and Clinical Pharmacology; 1(1): 9-21.

12. Gomez-Cabrera, M.C., Domenech, E., Romagnoli, M., Arduini, A., Borras, C., Pallardo, F.V.., Sastre, J. and Viña, J. (2008). Oral administration of vitamin $\mathrm{C}$ decreases muscle mitochondrial biogenesis and hampers training-induced adaptations in endurance performance. Am J Clin Nutr.; 87(1):142-9.

13. Bancroft, J.D. and Gamble, M. (2002). "Theory and Practice of Histological Techniques". 5th ed. New York: Churchill Livingstone; pp. 593-620.

14. Matsuoka-Sakata, A., Tamura, H., Asada, H., Miwa, I., Taketani, T., Yamagata, Y. and Sugino, N. (2006). Changes in vascular leakage and expression of angiopoietins in the corpus luteum during pregnancy in rats. Reproduction; 131(2):351-360.

15. White, C. W. and Martin, J. G. (2010). Chlorine Gas Inhalation: Human Clinical Evidence of Toxicity and Experience in Animal Models. Proc Am Thorac Soc.; 7. pp 257-263.

16. Gorguner, M., Aslan, S., Inandi, T. and Cakir, Z. (2004). Reactive airways dysfunction syndrome in housewives due to a bleach-hydrochloric acid mixture. Inhal Toxicol.; 16:87-91.

17. Yildirim, C., Kocoglu, H., Goksu, S., Cengiz, B., Sari, I. and Bagci, C. (2004). Long-term pulmonary histopathologic changes in rats following acute experimental exposure to chlorine gas. Inhal Toxicol.; 16(14):911-915.

18. Behcet, A.L., Selim, B., Cuma Y., Suat Z., İsmail T., Ayhan E., Yasemin B. and İbrahim S. (2010). Histopathological Study of Short and Long-Term Pulmonary Effects of Nebulized Sodium Bicarbonate Treatment in Chlorine Gas Exposured Rats. Turkiye Klinikleri J Med Sci.; 30(2):650-8

19. Peters, C.A., M.R., Fernandez, C.H., Stephan, J., Wiederschain, D.G. and Moses, M.H. (1997). Dysregulated proteolytic balance as the basis of excess extracellular matrix in fibrotic disease. Am. J.
Physiol.; 272: 1960-1965.

20. Uhal, B.D. (2008). The role of apoptosis in pulmonary fibrosis. Eur. Respir. Rev.; 17: 138-144.

21. Menaouar, A., Anglade, D., Baussand, P., Pelloux, A., Corboz, M., Lantuejoul, S., Benchetrit, G., Grimbert, F.A. (1997). Chlorine gas induced acute lung injury in isolated rabbit lung. Eur Respir J.;10:1100-1107.

22. Song, W., Wei, S., Zhou, Y., Lazrak, A., Liu, G., Londino, J.D., Squadrito, G.L. and Matalon, S. (2008). Inhibition of lung fluid clearance and epithelial $\mathrm{Na}+$ channels by chlorine, hypochlorous acid, and chloramines. Biol. Chem.; 118(2):752-762

23. Vadasz, I., Dada, L.A., Briva, A., Trejo, H.E., Welch, L.C., Chen, J., Tóth, P.T., Lecuona, E., Witters, L.A., Schumacker, P.T., Chandel, N.S., Seeger, W. and Sznajder, J.I. (2008). AMP-activated protein kinase regulates $\mathrm{CO} 2$-induced alveolar epithelial dysfunction in rats and human cells by promoting $\mathrm{Na}, \mathrm{K}$-ATPase endocytosis. J Clin Invest.; 285(13):752-762.

24. Martin, J. G., Campbell, H. R., Iijima, H., Gautrin, D., Malo, J.L., Eidelman, D.H., Hamid, Q. and Maghni, K. (2003). Chlorineinduced injury to the airways in mice. American Journal of Respiratory and Critical Care Medicine; 168(5):568-574.

25. Bell, D.G. (2008). Management of acute respiratory distress syndrome (ARDS) following chlorine exposure. Am J Respir Crit Care Med.; 176: A314.

26. Mo, Y., Chen, J., Humphrey, D.M., Fodah, R.A., Warawa, J.M. and Hoyle, G.W. (2015). Abnormal epithelial structure and chronic lung inflammation after repair of chlorine-induced airway injury. Am J Physiol Lung Cell Mol Physiol.;308(2):L168-178.

27. Font-Ribera, L., Kogevinas, M., Zock, J.P., Gómez, F.P., Barreiro, E., Nieuwenhuijsen, M.J., Fernandez, P., Lourencetti, C., Pérez-Olabarría, M., Bustamante, M., Marcos, R., Grimalt, J.O. and Villanueva, C.M. (2010). Short-term changes in respiratory biomarkers after swimming in a chlorinated pool. Environ Health Perspect.;118(11):1538-1544.

28. O'Koren, E.G., Hogan, B.L. and Gunn, M.D. (2013). Loss of basal cells precedes bronchiolitis obliteranslike pathological changes in a murine model of chlorine gas inhalation. Am J Respir Cell Mol Biol.; 49(5):788-97.

29. Sourour, D. A., EL Margoushy, N. M. and EL Nemr, 
G. M. (2012). Protective Effects of Vitamin C Against Benzene-Induced Lung Injury in Rats. Med. J. Cairo Univ., 80(1): 545-558.

30. Miller, K.A., Siscovick, D.S., Sheppard, L., Shepherd, K., Sullivan, J.H., Anderson, G.L. and Kaufman, J.D. (2007). Long-term exposure to air pollution and incidence of cardiovascular events in women. N. Engl. J. Med.; 356 (5): 447-58.

31. Tuck, S.A., Ramos-Barbón, D., Campbell, H., McGovern, T., Karmouty-Quintana, H. and Martin, J.G. (2008). Time course of airway remodelling after an acute chlorine gas exposure in mice. Respir Res.; 14; 9:61.

32. Banerjee, S., Chattopadhyay, R., Ghosh, A., Koley, H.,
Panda, K., Roy, S., Chattopadhyay, D. and Chatterjee, I.B. (2008). Cellular and molecular mechanisms of cigarette smoke-induced lung damage and prevention by vitamin C. J. Inflamm.; 11 (5): 21.

33. AL Saggaf, S.M., Ali, S.S., Ayuob, N.N., Ghada, A., abdel-hamid, G.A. and AL-Jahdali, N.H. (2010). Light and scanning microscopic study of the effect of car fuel (gasoline) inhalation on guinea pig respiratory system at station. Research Journal of Medical Sciences; 4: $38-47$.

34. Hemmati, A.A., Nazari, Z., Ranjbari, N. and Torfi, A. (2008). Comparison of the preventive effect of vitamin $\mathrm{C}$ and $\mathrm{E}$ on hexavalent chromium induced pulmonary fibrosis in rat. Inflammopharmacology; 16 (4): 195-7. 
الملخص العربى

الدور الوقائى لفيتامين ج ضد الأضرار التى يسببها الكلور للجرذان البيضاء البالغة : دراسة نسيجية

أمجد جابر السعيد ، ورحاب طلبه خطاب

قسم التشريح وعلم الأجنة، كلية الطب، جامعة عين شمس، مصر

المقدمة: تعتبر الرئة العضو الرئيسي لاستقبال المواد المهيجة المستنشقة . مادة الكلور لها قابلية عالية للذوبان بالماء. كائه كما أنه

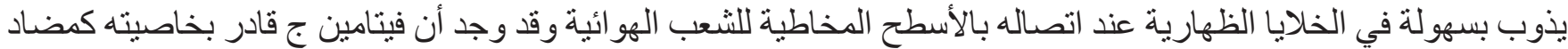
للأكسدة علي مقاومة تصلب الثر ايين المسببة بوساطة حهض الهيبة الهيدروكلوريك. إضافة إلى أن تناول فيتامين سي يقلل أكسدة الدهون و البروتينات في الجسم.

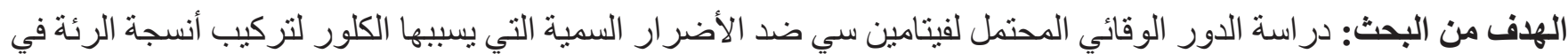

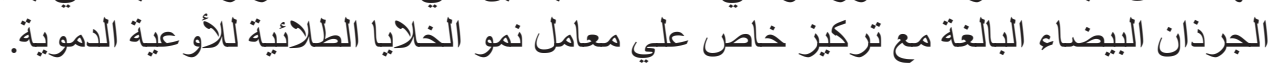

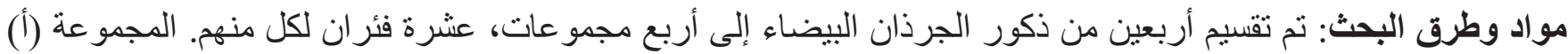

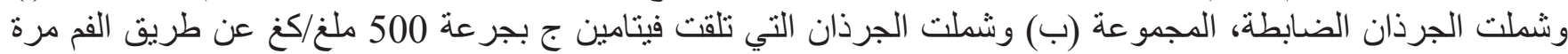

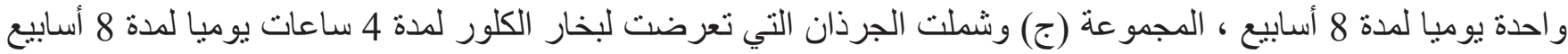

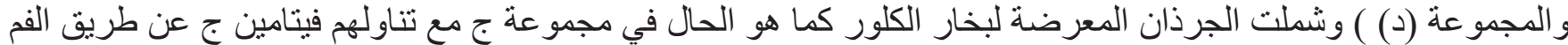

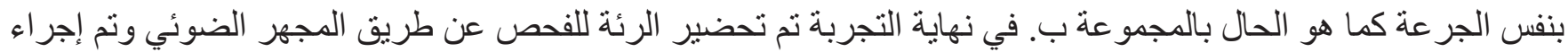

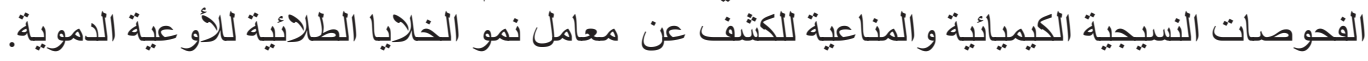

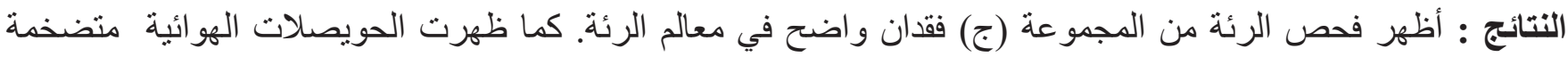

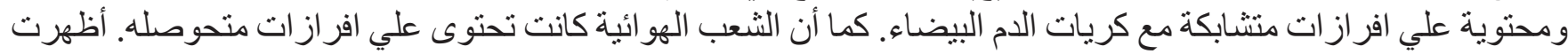
عينات الرئة المصبو غة بو اسطة صبغة ماسون زيادة ترسب الكو لاجين حول الثعب الهو ائية و الأوعية الدموية. كما أظهرت الثرات التهات

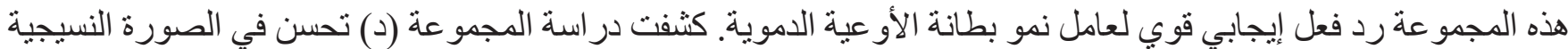

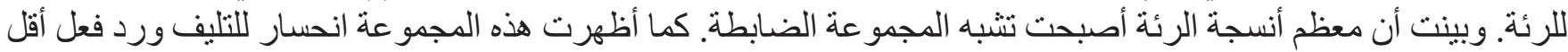
لعامل نمو بطانة الأوعية الدموية. الإستتتاج : للكلور آثار مدمرة على بنية الرئة، لكن فيتامين ج يمنالك القدرة على تخفيف هذه الآثار.

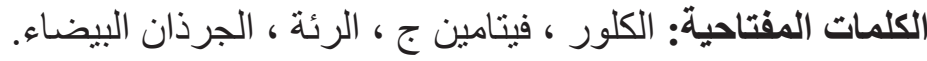

